\title{
Кумулативни глаголи у речницима чешког и српског језика
}

\section{Verbs with Cumulative Meaning in Czech and Serbian Dictionaries}

Катарина Митрићевић-Штепанек

(Београд, Србија)

\begin{abstract}
:
The paper deals with derived verbs in Czech and Serbian with prefix na-/на- meaning to accumulate bigger/big quantity of something. Based on lexicographical sources their meaning is specified, the equivalents and types of equivalence are identified, their semantization is analysed, and solutions in the form of dictionary entry additions are offered. It is concluded that cumulative verb derivatives are present in both languages, and that prefix na-/на- is very productive in that meaning. An analysis of their lexicographic entries shows that in the dictionary of Czech language the definition is precise and uniform, that certain earlier shortcomings in definition have been corrected in new dictionary of Serbian language, also that in Czech-Serbian dictionary the presentation and treatment of cumulative verbs have been approached in detail, and that semantization is mainly precise and well-thought-out.
\end{abstract}

\section{Key words:}

prefixal verbs; cumulative meaning; Czech language; Serbian language; equivalence; dictionary definition; semantization

\section{Апстракт:}

Рад се бави глаголским дериватима у чешком и српском језику грађеним префиксом па-/на- са значењем раяюом накуйити, наїомилати већу/велику количину чеїа. На основу лексикографске грађе прецизира се њихово значење, утврђују еквиваленти и типови еквиваленције, анализира преводна 
семантизација и нуде решења у виду допуне речничке одреднице. Закључује се да су глаголски деривати са значењем кумулативности присутни у оба језика а префикс па-/на- веома продуктиван у том значењу. Анализа њихове лексикографске обраде показује да је у речнику чешког језика дефиниција прецизна и уједначена, да су у новом речнику српског језика исправљени извесни ранији недостаци у дефинисању, те да је у чешко-српском речнику презентацији и обради кумулативних глагола приступљено детаљно и да је преводна семантизација углавном прецизна и добро промишљена.

\section{Кључне речи :}

префиксални деривати; кумулативни глаголи; чешки језик; српски језик; еквиваленција; речничка дефиниција; преводна семантизација

Предмет нашег рада су глаголски деривати у чешком и српском језику изведени префиксом па-/на- који изражавају значење раgюом накуӣuти, наїомилати већу/велику количину чеїа. ${ }^{1}$ Ти глаголи потпадају под ширу семантичку црту квантитета, и то велике количине радње, а у литератури о категорији акционалности називају се кумулативним.

За потребе истраживања грађу смо ексцерпирали из једнојезичних речника чешког и српског језика и двојезичног чешко-српског речника. ${ }^{2}$

На основу претходне литературе и лексикографске дефиниције маркирали смо глаголске изведенице са датим префиксом које изражавају семантику кумулативности у чешком и српском језику и прецизирали њихов семантички садржај. Потом смо анализирали типове еквиваленције - утврдили смо формалне и семантичке еквиваленте, ${ }^{3}$ прецизирали преводну семантизацију, анализирали обраду датих деривата у двојезичном речнику и понудили решења у виду извесних допуна дефиниције значења у оквиру појединих одредница.

1 У раду се у знатној мери ослањамо на материјал и истраживање из наше необјављене докторске дисертације. Видети MITRIĆEVIĆ-ŠTEPANEK, K.: Glagolski prefiksi u funkciji izražavanja količine radnje u češkom i srpskom jeziku. Doktorska disertacija. Beograd: Filološki fakultet, 2015 .

2 To cy: HAVRÁNEK, B. - BĚLIČ, J. - HELCL, M. - JEDLIČKA, A. (eds.): Slovník spisovného jazyka českého I-IV. Praha: Československá akademie věd, 1960-1971 (даље SSJČ); SVOZILOVÁ, N. PROUZOVÁ, H. - JIRSOVÁ, A.: Slovník slovesných, substantivních a adjektivních vazeb a spojení. Praha: Academia, 2005 (даље SV); STEVANOVIĆ, M. et al. (eds.): Rečnik srpskohrvatskoga književnog jezika I-VI. Novi Sad: Matica srpska, 1967-1976 (даље PMC); VUJANIĆ, M. et al. Rečnik srpskoga jezika. Novi Sad: Matica srpska 2011 (даље PCJ); KAČANIK, E. et al.: Češko-srpski rečnik I, II. Beograd: SANU, 2001 (даље ЧСР).

3 Формалне и семантичке еквиваленте објашњавамо даље у тексту. Видети нап. 14. 
У литератури о чешком језику нпр. Nový encyklopedický slovník у одредници под називом Způsob slovesného děje издваја и кумулативне глаголе наводећи: „Kumulativní skupina obsahuje kumulativa, která označují uchopení blíže neurčené kvantity objektu; charakteristické je pro ně užití s gen. n. s označením množství v akuz.: nabalit (věci, mnoho věcí), nahrabat (mnoho)....4 Деривати са тим значењем обрађују се и у бројним другим излагањима о префиксалним глаголима. ${ }^{5}$

Семантика раяюом накуйити, наїомилати већу/велику количину чеїа у чешком језику у SSFČ обухваћена је значењем префикса па- под бројем 6. као „provedení děje v potřebné, zamýšlené $n$. velké míře...“ и додаје ce „jde-li o věcný význam předmětu děje, se 4.p., jde-li o množství, zprav. velké, s 2.p.: nasbírat jahody (tj. ne maliny ap.) nasbírat jahod (tj. něj. množství jahod)“. У питању су дакле транзитивни глаголи, и то двовалентни. Њихова глаголска рекција подразумева објекат у генитиву, који изражава велику (или довољну) количину радње, или у акузативу, који пак изражава неутралну количину радње. У речнику је у одредници уз дати глагол у загради наведена рекција, нпр. nakosit (co, při důrazu na množství čeho) kosou n. srpem nasekat: n. trávu, trávy. ${ }^{6}$

Међутим, ове изведенице могу изражавати дато значење и уз објекат у акузативу, али он мора бити проширен одређеним квантитативним елементом, нпр.: Rodiče dětem našetřili nezanedbatelnou částku. Анализом деривата у $S V$ утврђујемо да се углавном не прецизира генитивна рекција кумулативних глагола који су њиме обухваћени и да контекстуални примери садрже квантитативне елементе, а да је знатно ређи поступак који обухвата граматичке податке и егземплификацију на основу генитивне рекције.

načesat něco (česáním naplnit) Na chmelové brigádě někteří z nás načesali denně až patnáct věrtelů chmele.

nachytat někoho (o zvířeti) Rybáři nachytali spoustu ryb.

nanosit něco Děti zase nanosily do předsíně spoustu bláta na botách.

nakupit něco (shromáždit ve větším množství) Komise nakupila řadu důkazů o senátorových proviněních.

4 KARLÍK, P. - NEKULA, M. - PLESKALOVÁ, J. (eds.): Nový encyklopedický slovník češtiny. Praha: NLN, 2016, s. 2130.

5 Видети нпр. ČECHOVÁ, M. et al.: Čeština - řě a jazyk. Praha: ISV nakladatelství, 20oo, s. 140; ŠMILAUER, V.: Novočeské tvoření slov. Praha: SPN, 1971, s. 182; KARLÍK, P. - NEKULA, M. - RUSÍNOVÁ, Z. (eds.): Př́ruční mluvnice češtiny. Praha: NLN, 1996, s. 210; DOKULIL, M. - HORÁLEK, K. HŮRKOVÁ, J. (eds.): Mluvnice češtiny I: Fonetika, Fonologie, Morfonologie a morfemika, Tvoření slov. Praha: Academia, 1986, s. 396; UHER, F.: Slovesné předpony. Brno: Univerzita J.E. Purkyně, 1987, s. 70, 73-74; ŠTÍCHA, F. a kol.: Velká akademická gramatika spisovné češtiny I. Morfologie: Druhy slov, Tvoření slov. Část 2. Praha: Academia, 2018, s. 1038.

6 Примере из речника наводимо у вези са анализираним значењем, тако да су неки елементи одреднице које не сматрамо неопходним испуштени. 
nashromáždit něco Česká šlechta kdysi nashromáždila velký majetek. naslibovat něco Když teta odjížděla, naslibovala dětem plno dárků.

nadělat něco expr. něčeho Ty děti nadělají rámusu.

namluvit něčeho Sousedka namluví řečí, ale skutek utek'.

У речнику $S S \mathcal{} C \check{C}$ дефиниција значења кумулативних глагола подразумева опис - извршити мноіо раgюе или извршити раgюу (йо йравилу) у великој/већој/ /знатној количини, мноіо извршити, те је тако наглашен квантитативни елемент значења лексеме, а ређе и често, мної йута извршити раgюу, где је дуративност повезана са квантитетом.

nabalit zabalit mnoho něčeho

nakázat sdělit mnoho kázáním; mnoho napovídat naslibovat mnoho (věcí) slíbit, mnohokrát slíbit

nakoupit koupit, zprav. ve větším množství napáchat ve větším množství n. opětovaně spáchat nastřílet střilením ulovit ve větším množství navařit vařením připravit (často ve větším množství)

\section{naplodit ve velkém počtu}

namačkat mačkáním něčeho vytvořit (zprav. v hojné míře)

napříst předením $\mathbf{v}$ značném množství vytvořit

Што се тиче дефиниције путем синонима у наведеном речнику, код кумулативног значења најчешће су то изведенице грађене истим префиксом и обично су наведене иза описа значења, те се ради о комбинованој дефиницији, док се самостално наводе врло ретко.

nabásnit nabájit, nalhat

nabučet namluvit, napovídat, natlachat, nažvanit

nařečnit namluvit, napovídat; natlachat, nahovořit

narvat natrhat; naškubat

naškudlit našetřit, naspořit, naškrtit

Примери дефиниције путем синонима са неким другим префиксом су малобројни, што потврђује да се најчешће само деривати са префиксом nадоводе у везу са значењем кумулативности. 
namudrovat vymudrovat, vymyslet

našpinit ušpinit, zašpinit

Изведенице са значењем кумулативности могу бити како моносемичне тако и полисемичне. ${ }^{7}$ Моносемичне су на пример:

nabájit (co, při důrazu na množství čeho) vymyslit mnoho bájí; expr. povědět mnoho smyšlenek

nadolovat (co, při důrazu na množství čeho) dolováním získat, shromáždit

nahospodařit (co; komu co) hospodařením našetřit

nakřečkovat dok. hanl. (co, při důrazu na množství čeho) chamtivě nashromáždit, nahromadit

nakuchtit expr. (co) navařit

nakutat (co, při důraze na množství čeho) vytěžit, dobýt, nakopat

naplenit (co, při důrazu na množství čeho) pleněním nashromáždit

našidit expr. (co) šizením získat, nahromadit

našveholit dok. (toho) mnoho a často šveholit; expr. namluvit, napovídat

natvořit (co, koho, při důrazu na množství čeho) vytvořit $\mathrm{v}$ jistém množství

navyrábět (co, při důrazu na množství čeho) postupně (ve větším množství) vyrobit

Код полисемичних глагола, кумулативност се јавља као инваријантно и варијантно значење.

Уколико је значење инваријантно, има примера да и варијантно, одн. нека од варијантних значења такође изражавају кумулативност, а често се ради о метафоричном преносу на секундарна значења.

nadřít 1. (co, při důrazu na množství čeho) stahováním, dřením s něčeho něco opatřit, získat; 2. expr. (co) namáhavě n. hrabivě získat, nahospodařit; vydřít

naflákat ob. expr. 1. (komu) nabít, natlouci; 2. (čeho) hodně, zprav. nepečlivě nadělat nakukat 1 . řidč. (co, při důraze na množství čeho) vyjádřit kukáním; 2. ob. expr. (co komu) namluvit, napovídat (zprav. něco nepravdivého)

nalapat 1. (koho, co, při důrazu na množství čeho) lapáním ve větším množství pochytat; nachytat; 2. expr. (koho, co) přistihnout, dopadnout, chytit, nachytat; 3. (co, při důrazu na množství čeho) nadechnout, nadýchat se

7 У вези са питањем моносемије или полисемије глаголских лексема ми не доводимо у питање дефиницију значења коју наводи $S S \mathcal{}$, а посебно се то односи на она секундарна значења за која аутори у уводу кажу: „Samostatně nejsou uváděny... významy slov vzniklé přenesením a dosud neustálené v samostatný význam (nelexikalizované)“. То значи да као моносемичне схватамо све оне лексеме чије семеме нису одвојене бројевима 1., 2., итд. 
namlít 1. (co, při důrazu na množství čeho) vyrobit mletím, semlít; 2. ob. expr. (čeho) namluvit, napovídat, natlachat, nažvanit; 3. ob. expr. (komu) nabít, natlouci, namlátit, natř́skat

napleskat expr. 1. (komu) naplácat; 2. řidč. (co, při důrazu na množství čeho) nevkusně nahromadit, splácat dohromady; 3. ob. (co, při dưrazu na množství čeho) napovídat, naplácat, nažvanit

narvat 1 . ob. expr. (co, při důrazu na množství čeho) rvaním, škubáním natrhat; naškubat; 2. ob. expr. (co) pro sebe získat; nashromáždit; 3. zhrub. (co) vrchovatě naplnit, přeplnit

nasekat 1. (co, při důrazu na množství čeho) sekáním připravit k spotřebě; 2. ob. expr. (komu) nabít, natlouci, namlátit, natřískat; 3. ob. expr. (co, při důrazu na množství čeho) sekáním nadělat

Код једног ठроја глагола испољава се као варијантно примарно, просторно значење префикса па- радюом нанети, сместити на йовршину нечеїа, или значење исйуюавања унутрашњости.

naháčkovat (co) 1. háčkováním ve větším množství vyrobit; uháčkovat; 2. háčkováním připojit

naházet 1. (co, při důrazu na množství čeho) házením někde umístit, nahromadit, někam dopravit; expr. $n$. věci do kufru rychle složit; n. na sebe šaty rychle se obléci, n. do sebe oběd ve spěchu sníst; 2. (co) házením vytvořit; navršit, navrstvit

nahrát 1. (čeho) mnoho zahrát; 3. hud. n. skladbu zahrát ji pro zvukový záznam; tech. provést zvukový záznam na zvukový pás, fólii ap.

nanést 1. (co, při důrazu na množství čeho, co, čeho kam, komu) ve větším množství přinést, snést na jedno místo, nesením n. nošením nahromadit; nanosit; 2. (co) nesením vytvořit; 3. (co nač) po povrchu něčeho lehce, rovnoměrně rozetřít, rozhrnout, dát tenkou vrstvu něčeho na něco

nacpat 1. (co, při důrazu na množství čeho, kam) natlačit, namačkat, napěchovat, nastrkat, nabít; přen. ob. expr. nacpal do rádia už hrůzu peněz investoval; n. se do tramvaje; ob. všude n. papíry dát, položit; 2. (co, zř. expr. koho čím) naplnit, nadít, přeplnit

napakovat ob. 1. (co, při důrazu na množství čeho, komu, kam) nabalit; 2. (koho, 4. p.) opatřit hojně zásobami na cestu

О антонимичним значењима деривата са префиксом па- сведоче глаголи чије је варијантно значење gелимично извршење раgюе.

nařezat 1. (co, při důrazu na množství čeho) řezáním oddělit, upravit, připravit, získat, opatřit; 2. (co) začít řezat, udělat na něčem zářez, zářezy 
natlouci 1. (co, při důrazu na množství čeho, kam) tlučením vpravit (ve větším počtu); zatlouci, zarazit, nabít; 5. (co) trochu rozbít

Кумулативност се испољава и као варијантно значење у бројним примерима, а инваријантна значења изведеница су семантички разнолика. Ради се нпр. о просторним значењима наношена на йовршину, навлачена на објекат, исйуюавањ у унутрашњости, ирравца раяње у ширину итд., такође је присутна семантика мале количине радње, али знатно ређе.

nakovat 1. (co) přikovat; 2. (co, při důrazu na množství čeho) kováním nadělat, vyrobit; nakout

napíchat 1 . (co, koho) píchnutím postupně na něco upevnit, na něčem zachytit; nabodat; 2. (co) postupně do něčeho zapíchnout; nabodat, nastrkat; 3. (co, při důrazu na množství čeho, do čeho) pícháním vytvořit (dírky ap.)

naválet 1 . řidč. (co) válením někam dopravit, někde nahromadit; navalit; 2. (co, při důrazu na množství čeho) válením uhníst

naklepat 1. (co) klepáním nějak zpracovat, upravit, připravit; 2. expr. (komu) nabít, natlouci; porazit (koho); 5. expr. (co o kom, komu) napovídat klepů; naklevetit namačkat 1. (co kam) natlačit, natěsnat, vtěsnat; 2. (co) přeplnit; 3. (co, při důrazu na množství čeho) mačkáním něčeho vytvořit (zprav. v hojné míře)

natřepat 1. (co) třepáním, třesením načechrat; natřást; 2. řidč. (co, při důrazu na množství čeho) natřást, setřást; 3. expr. (komu; komu co) nabít, natlouci

našpinit 1. (co) trochu ušpinit; 2. (co, při důrazu na množství čeho) ušpinit, zašpinit

Што се тиче српског језика, префиксалним дериватима са семантиком нагомилавања такође је посвећена пажња у литератури о глаголским префиксима и категорији акционалности. ${ }^{8}$

Значење изведеница раgюом накуйити, наїомилати већу/велику количину чеїа у РМС је дефинисано у оквиру префикса на-: „1. у сложеним глаголима кад указују на већу, обилну меру извршења какве радње значећи... обухватање веће масе предмета, веће количине чега: набрати, нацедити, начупати, накувати“. Запажамо да је значење велике количине наведено на првом месту, док је тек

8 Види: STEVANOVIĆ, M.: Savremeni srpskohrvatski jezik I: Gramatički sistemi i književnojezička norma. Beograd: Naučno delo, 1964, s. 438; STEVANOVIĆ, M.: Savremeni srpskohrvatski jezik II: Sintaksa. Beograd: Naučna knjiga, 1974, s. 540; KLAJN, I.: Tvorba reči u savremenom srpskom jeziku I: Slaganje i prefiksacija. Beograd: Zavod za udžbenike i nastavna sredstva: Institut za srpski jezik SANU; Novi Sad: Matica srpska, 2002, s. 258.; BELIĆ, A.: Savremeni srpskohrvatski književni jezik II: Nauka o građenju reči. Beograd: Naučna knjiga, 1949, s. 301; TOŠOVIČ, B.: Sposoby glagol'nogo dejstvija v serbskom, chorvatskom i bošnjackom jazykach.. Katowice: Wydawnictvo Uniwersytetu Şląskiego, 2009, s. 34; IVANOVIĆ, M.: Izražavanje akcionalnosti u ukrajinskom i srpskom jeziku. Doktorska disertacija. Beograd: Filološki fakultet, 2013, s. 313-314. 
на трећем месту наведено просторно значење префикса. ${ }^{9}$ Објекат у генитиву није наведен експлицитно одговарајућим питањем за падеж (кога, чега) као што је то био случај у $S S \mathcal{} C$, али је ипак у егземплификацији исказан.

награбити Награби у кречани [креча]... Гршо награби смокава...

накидати Мене оправише у врт да накидам за чорбу зелена першуна и мирођије.

наломити изломити одређену (обично већу) количину нечега, ломећи припремити, накупити: хлеба, грања.

наплести Да... наплетем ловорових венаца.

натргати Натрга грања и стави га пода се.

нахватати А чим нахвата [рибе]... за једну пошиљку... он нагне кући.

Објекат међутим може бити и у акузативу, исто као што је случај у чешком језику: Кажу gа су неїдје іаgно намлатили Талијане.

Дефинисање значења кумулативних глагола у $P M C$ није јединствено као што

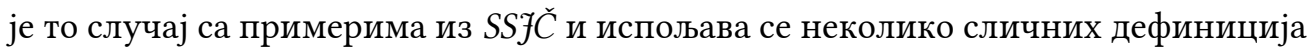
и њихових варијанти. Код неких глагола дефиниција се даје као извршити раgюу у већој/великој количини, а код других се ради о gовољној/извесној/ogређ еној количини.

набацати бацити у великој количини на гомилу

напрати опрати велику количину чега

налупати разбити, разлупати у одређеној, обично већој количини

нагулити доста огулити, ољуштити чега у већој количини

намесити месећи припремити у већој количини, умесити довољну количину

наотимати насилним одузимањем прикупити велику количину чега

натрести тресући (дрво) омлатити већу количину чега

накупити скупити довољну количину чега ${ }^{10}$

намусти помусти довољну количину (млека) $)^{11}$

наслати послати у довољној количини, много

натесати истесати у довољној количини

навадити вадећи нагомилати, довољно извадити ${ }^{12}$

9 Исти принцип примењен је и у РCJ.

10 У $P C J$ је дефиниција значења кумулативних глагола прецизнија: купећи сакупити, прикупити, сабрати нешто у некој, обично већој или довољној количини.

11 У РСЈ: помусти неку, обично већу или довољьну количину (млека).

12 У РСЈ: вадећи скупити, извадити неку, обично већу или довольну количину. 
накосити косећи припремити извесну количину (траве) наљуштити ољуштити одређену количину нечега

Ређе је присутно тумачење значења путем синонима, а заступљене су изведенице са истим префиксом, у мањем броју са неким другим префиксом који изражава велику количину радње - у овом случају ради се о префиксу изу значењу извршень раяюе у довољној мери, у йотйуности, gо краја, ${ }^{13}$ или су то префиксални глаголи са значењем чисте иерфективности допуњени неким квантитативним изразом којим се прецизира дата семантика.

навадити вадећи нагомилати, довољно извадити

нажети накупити, набрати жањући

накрасти крађом накупити

напридиковати много напричати

наловити нахватати у лову, ловећи

накамчити испросити, измолити камчењем, довољно искамчити

напричати врло много испричати

наштедети штедњом накупити, доста уштедети

наорати узорати (обично више земље)

натаманити доста, у довољном броју утаманити, уништити

Кумулативни глаголи у српском језику такође могу бити моносемични и полисемични. Моносемични су нпр.:

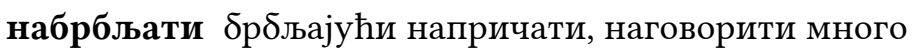
навадити вадећи нагомилати, довољно извадити наприповедати исприповедати обухватајући доста ствари, напричати настругати стругањем припремити извесну (обично већу) количину чега, истругати

Код полисемичних глагола ово значење испољава се и као инваријантно и као варијантно значење.

Има примера код којих и варијанта или нека од варијанти имају исту семантику нагомилавања, и као у чешком језику, такође се ради о пренесеним, метафоричним значењима.

наковати 1 исковати велику количину нечега (нпр. новаца); 2. фиг. напричати неистине, налагати

13 О овом значењу говоримо детаљније даље у тексту. 
нагулити 1. доста огулити, ољуштити чега у већој количини; 2. а. начупати, накидати; $\delta$. накупити доста новца зеленашењем, лихварством

Понекад је као варијантно значење присутна мала количина радња, чиме префикс уноси у мотивни глагол антонимична значења, а у неким примерима и просторно значење смештања на йовриину.

напећи 1. испећи довољну количину чега; 2. при печењу захватити ватром део нечега, нагорети

насећи 1. припремити секући, исећи, посећи у довољној количини; 2. почети сећи; засећи

набацати 1 . бацити у великој количини на гомилу, бацајући направити велику гомилу; 2. сместити, нагомилати без реда; 3. насути одозго, прекрити

Мала количина радње, или пак просторно значење, конкретно навлачене на објекат, може бити присутно и као инваријантно значење.

наломити 1. изазвати пукотину, напрслину на нечему; изломити с краја, заломити, окрњити; 2. изломити одређену (обично већу) количину нечега, ломећи припремити, накупити

насушити 1. мало осушити; 2. осушити у довољној количини, много

навући 1. а. вукући ставити што преко чега, тако да покрије или обухвати, натаћи што; б. обући, обути (одело, обућу). в. набити, натући (на главу); 2. довући, нагомилати

Што се тиче еквиваленције, значење кумулативности чешких изведеница са префиксом па- у преводној семантизацији у ЧСР дефинисано је навођењем еквивалента уз прецизирање рекције елементима мноїо/ӣyнo/gocma чеīa/moīa, који указују на велику количину.

На основу анализе грађе из датог речника утврђујемо два типа еквиваленције - формалну и семантичку. ${ }^{14}$ Према бројности су на првом месту заступљени формални еквиваленти.

14 Формалним еквивалентом сматрамо у овом и свим другим случајевима глагол грађен истим творбеним формантом - творбени еквивалент, са истим, или приближним значењем. Еквиваленцију наравно посматрамо у оквиру семеме, а код полисемије у чешком језику узимамо у обзир и наводимо еквиваленте само у вези са значењем кумулативности, евент. велике количине радње. Уколико нема формалне еквиваленције, семантички еквивалент представља дериват са неким другим префиксом који има исто или приближно значење као и његов пандан, или пак беспрефиксални глагол такође са истим или приближним значењем, а у оба случаја семантика може бити прецизирана неким елементом, најчешће квантитативним. 


\begin{tabular}{|c|c|}
\hline nabrebentit ob. expr. & 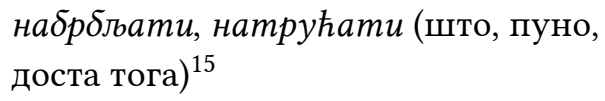 \\
\hline načesat & набрати (што, много тога) \\
\hline nadojit & намусти (што, много тога) \\
\hline nadrat & начуӣати (што, доста тога) \\
\hline nadrmolit & $\begin{array}{l}\text { натртьљати, набрбльати (чега, } \\
\text { доста тога) }\end{array}$ \\
\hline nachytat & нахватати (што, много тога) \\
\hline nakecat & $\begin{array}{l}\text { натрућати, набрбљати (што, доста } \\
\text { тога) }\end{array}$ \\
\hline nakosit & накосити (што, много тога) \\
\hline naklábosit hanl. & $\begin{array}{l}\text { наблебетати, натрућати (што, } \\
\text { много тога) }\end{array}$ \\
\hline nakoupit & накуӣовати (што, много тога) \\
\hline nakřápat zhrub. & натрућати (што, много тога) ${ }^{17}$ \\
\hline nakrást & накрасти (што, доста тога) \\
\hline nalakotit & $\begin{array}{l}\text { наїрамзити, наїрабити (што, доста } \\
\text { тога) }\end{array}$ \\
\hline nalámat & наломити (чега) \\
\hline nalhat & $\begin{array}{l}\text { налаїати, найричати лажи (коме, } \\
\text { што, много тога) }\end{array}$ \\
\hline naloupit & найљачкати (што) \\
\hline nalovit & наловити (што, доста тога) \\
\hline
\end{tabular}

15 С обзиром да се ради о разговорној и експресивној лексеми у чешком језику, по нашем мишљењу одговарао би дериват наторокати који наводи $P C J$ и дефинише га много, којешта напричати, изблебетати, избрбљати.

16 Могао би бити наведен и глагол набалезгати који се у РСJ дефинише напричати много глупости, бесмислица, гадости, уз стилски квалификатор пејоративности (пеј.), тако да по нашем мишљењу сасвим одговара чешком пандану.

17 По нашем мишљењу као еквивалент би могла бити наведена и изведеница натрабуғати од мотивног глагола трабуюати „говорити бесмислено, булазнити“ (видети $P M C$ ) који својом негативном конотацијом одговара чешкој лексеми. 


\begin{tabular}{|c|c|}
\hline naskládat & наслаїати (што, пуно тога) \\
\hline nasmažit & найржити (што, пуно чега) \\
\hline nastrouhat & $\begin{array}{l}\text { наструїати, нарибати (што, много } \\
\text { чега) }\end{array}$ \\
\hline nasušit & насушити (што, много чега) \\
\hline našit & нашити (што, много чега) \\
\hline naškemrat expr. & начмизярити \\
\hline naškubat & $\begin{array}{l}\text { начуйати, накияати (што, много } \\
\text { чега) }\end{array}$ \\
\hline $\begin{array}{l}\text { naštěbetat štěbetáním vyjádřit; expr. } \\
\text { mnoho namluvit, napovídat }\end{array}$ & $\begin{array}{l}\text { 1. нацвркутати; 2. експр. } \\
\text { набрбльати (што, пуно чега) }\end{array}$ \\
\hline naštípat & нацейати, насећи (што, пуно чега) \\
\hline natahat & начуйати (што, пуно чега) \\
\hline natlachat ob. expr. & $\begin{array}{l}\text { набрбљьати, найричати (што, пуно } \\
\text { чега) })^{18}\end{array}$ \\
\hline natrást & натрести (што, пуно чега) \\
\hline nažít, nažnout & $\begin{array}{l}\text { нажьети, нажети, накосити (што, } \\
\text { много чега) }\end{array}$ \\
\hline nažvanit expr. & $\begin{array}{l}\text { набрбльати, натрућати (што, } \\
\text { много чега) }\end{array}$ \\
\hline nažebrat & найросити (што, много чега) \\
\hline
\end{tabular}

Код овог типа еквиваленције има случајева конвергенције - више лексема у чешком језику има исти формални еквивалент у српском.

\begin{tabular}{ll}
\hline nahovořit & найричати (што, много тога) \\
\hline nařečnit & $\begin{array}{l}\text { наїоворити, найричати (што, пуно } \\
\text { тога) }\end{array}$ \\
\hline namluvit & найричати (што, много тога) \\
\hline
\end{tabular}

18 С обзиром да је чешка лексема експресивно обојена, као преводни еквивалент могао би бити наведен и глагол натрућати од мотивног глагола трућати „бесмислено, којешта говорити, наклапати“ (видети $P M C$ ). 


\begin{tabular}{|c|c|}
\hline napovidat & $\begin{array}{l}\text { найричати, исириччати (коме што, } \\
\text { много тога) }{ }^{19}\end{array}$ \\
\hline nastřádat & наштеgети, (што, много чега) \\
\hline našetřit & наштеgети (што, много чега) \\
\hline naškrtit ob. expr. & наштеgети (новац) \\
\hline
\end{tabular}

У неким случајевима лексему у чешком језику заступа лексема у српском језику која има шири обим значења, а код преводне семантизације треба прецизирати значење додавањем контекстне карактеристике у загради, што се углавном и примењује у ЧСР.

\begin{tabular}{ll}
\hline nakydat & набацати (об. ђубре) $)^{20}$ \\
\hline napršet & найagamu (о киши) \\
\hline narubat & насећu (дрва) \\
\hline nastřihat, nastřihat & насећu, изрезати (маказама) \\
\hline
\end{tabular}

Наилазимо и на појаву дивергенције која подразумева однос у ком појединачне семеме у чешком језику имају своје еквиваленте у српском језику у виду лексема. То се дешава када код полисемичног глагола у чешком језику више семема има значење кумулативности и свака има свој формални еквивалент у српском језику.

\section{nahrabat}

1. (co, při důrazu na množství čeho) наіррабуљьти, зірннтии (што, много hrabáním shromáždit

3. ob. expr. (co, čeho) hrabivě тога) nashromáždit, získat; nalakotit зірнути, наїрабити

\section{naplácat}

2. (co, při důrazu na množství čeho) набацати (што, много тога) mnoho a neuspořádaně, ledabyle naházet, nanést, nadělat

19 Сви овде наведени деривати у чешком језику могу имати за преводне еквиваленте глаголе наговорити, напричати, мада нису увек оба наведена у ЧСР, као што се види из примера.

20 Лексема kydat у чешком језику има прецизирано значење „бацати, избацивати балегу“, а секундарно значење је у вези са тим најчешће експресивно и значи „бацати на некога љагу“. То значи да је истоветан семантички садржај у оба језика везан само за изражавање тог секундарног значења. 
3. ob. (co, při důrazu na množství

набрбльати, натрућати (што, čeho) napovídat, nažvanit много тога)

narvat

1. ob. expr. (co, při důrazu na množství накиgати, набрати (што, много čeho) rvaním, škubáním natrhat; $\quad$ тога); naškubat

2. ob. expr. (co) pro sebe získat наїрабити

\section{nařezat}

1. (co, při důrazu na množství čeho) нарезати, насећи (што, пуно тога) řezáním oddělit, upravit, připravit, získat, opatřit

4. ob. expr. n. peněz vydělat (peníze) намлатити ${ }^{21}$

\section{natrhat}

1. (co, při důrazu na množství čeho) начуӣати, накияати, набрати (што, trháním shromáždit jisté množství něčeho

2. (co, při důrazu na množství čeho) исцейamu, искиgати (пуно чега) ${ }^{22}$ trháním z něj. celku (kusu) získat, opatřit

У вези са формалном еквиваленцијом примећујемо да има примера у ЧСР код кумулативног значења да се предност даје изведеници са префиксом из-. Понекад је она присутна као једини еквивалент, иако смо у једнојезичном речнику наишли и на изведеницу са префиксом на-, или је пак наведена на првом или на другом месту уз ону са префиксом на-. У случајевима када префикс на- код полисемичних глагола уноси различиту семантику, значење кумулативности ван контекста не мора бити препознато, те се за лексикографски еквивалент бира онај који јасније указује на дату семантику. Често тада избор пада на префикс из- у значењу чисте иерфективности, али присутни су и други чисто видски или модификациони префикси уз дефинисање објекатске рекције. Избегавање употребе неадекватног формалног еквивалента је неопходно и процена је од суштинске важности за олакшавање

21 Значење под 4 није наведено у ЧСР. Сматрамо да би као преводни еквивалент могао бити употребљен глагол који смо навели, који је фреквентан у фрази „намлатити паре“.

22 Значење под 2 чешке изведенице такође по нашем мишљењу има преводне еквиваленте у виду глагола нацепати, накидати, али нису у ЧСР наведени, већ је предност дата дериватима са префиксом из-. 
коришћења речника, посебно због тога што у преводним речницима нема довољно места за детаљну преводну семантизацију. ${ }^{23}$

\begin{tabular}{|c|c|}
\hline napríst & $\begin{array}{l}\text { найрести, исйрести (што, много } \\
\text { тога) }\end{array}$ \\
\hline nakovat & $\begin{array}{l}\text { исковати, наковати (што, доста } \\
\text { тога) }\end{array}$ \\
\hline nakopat & $\begin{array}{l}\text { накойати, искойати (што, много } \\
\text { тога) }\end{array}$ \\
\hline naplést & $\begin{array}{l}\text { исйлести (што, много тога) } \\
\text { найлести (чега) }\end{array}$ \\
\hline napéci & найећu, исиеећu (што, много тога) \\
\hline
\end{tabular}

\begin{tabular}{|c|c|}
\hline nakourit & заgимити, наgимити (где) \\
\hline naloupat & $\begin{array}{l}\text { наљьуштити, ољьитити (што, } \\
\text { много тога) }\end{array}$ \\
\hline nasbirat & $\begin{array}{l}\text { накуйити, скуӣuти (што, пуно } \\
\text { тога) }\end{array}$ \\
\hline navozit & $\begin{array}{l}\text { навести, навућu, gойремити (што, } \\
\text { пуно чега) }\end{array}$ \\
\hline navláčet & навућu, gовућu (што, пуно чега, где) \\
\hline naslibovat & наобећавати (што), много обећати \\
\hline napíchat & $\begin{array}{l}\text { избости, избушити (што, доста } \\
\text { тога) (ЧСР) } \\
\text { набости }(\text { РМС) }\end{array}$ \\
\hline natěžit & $\begin{array}{l}\text { искойати (што, пуно чега) (ЧСР) } \\
\text { накойати (угља, руде) (РМС) }\end{array}$ \\
\hline
\end{tabular}

23 Тако се поступа нпр. у Чешко-српском и српско-чешком речнику, нпр. nařezat - избити (кога). Видети KOPRIVICA, V.: Češko-srpski i srpsko-češki rečnik. Beograd: Agencija Matić, 2008. 


\begin{tabular}{|c|c|}
\hline nastavět & 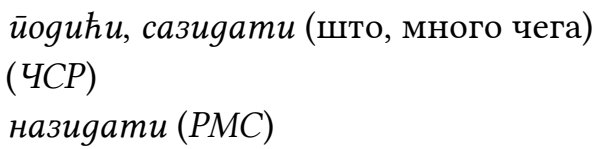 \\
\hline naškrábat & $\begin{array}{l}\text { ољуиттити, оіуулити, оструїати } \\
\text { (што, много чега) (ЧСР) } \\
\text { наі̄улити, наљуитити (РМС) }\end{array}$ \\
\hline navézt & $\begin{array}{l}\text { gовести, gотерати (што, много } \\
\text { чега) (ЧСР) } \\
\text { навести }(\text { РМС) }\end{array}$ \\
\hline naspořit & $\begin{array}{l}\text { уштеgети, заштеgети (што, пуно } \\
\text { тога) (ЧСР) } \\
\text { наштеgети }(\text { РМС) }\end{array}$ \\
\hline
\end{tabular}

Што се тиче семантичке еквиваленције, најбројније еквиваленте овог типа чине глаголи с префиксом из-. Префикс у изведенице уноси нпр. значење извршење раяюе у gовољьој мери, у йотӣуности, gо краја, затим значење резултативности, или су то само благе семантичке нијансе у оквиру значења чисте иерффективности. ${ }^{24}$ Ове изведенице представљају у недостатку формалног еквивалента најприближнији и најпрецизнији начин транспозиције јер поседују значење, или бар нијансу значења, сатуративности које се повезује са семом квантитета.

\begin{tabular}{ll}
\hline $\begin{array}{l}\text { nacákat } \\
\text { nastř́kat, našplíchat }\end{array}$ & $\begin{array}{l}\text { исирскати (кога) } \\
\text { сасвим попрскати, све редом } \\
\text { попрскати }\end{array}$ \\
\hline $\begin{array}{l}\text { nafackovat ob. } \\
\text { dát hodně facek, políčků }\end{array}$ & $\begin{array}{l}\text { ищамарати (кога) } \\
\text { истући, изударати шамарима }\end{array}$ \\
\hline namudrovat poněk. hanl. & измуgровати (што, доста тога)
\end{tabular}

24 О значењима префикса из- видети: KLAJN, I.: Tvorba reči u savremenom srpskom jeziku I: Slaganje i prefiksacija. Beograd: Zavod za udžbenike i nastavna sredstva: Institut za srpski jezik SANU; Novi Sad: Matica srpska, 2002, s. 255-256, те STEVANOVIĆ, M.: Savremeni srpskohrvatski jezik I: Gramatički sistemi i književnojezička norma. Beograd: Naučno delo, 1964, s. 456. И. Грицкат га дефинише као „вршење до постигнућа циља, до исцрпљивања могућности одн. интереса за радњу“ и додаје у вези са чисто видским значењима овог префикса да „има глагола који на извесне начине и значе напредовање ка таквом циљу, те се уз њих описана лексичка функција префикса из- растапа у граматичку...", дајући примере шибати : ишибати, тући : истући, мрцварти : измрцварити итд. Видети ГРИЦКАТ, И.: Префиксација као средство граматичке (чисте) перфектизације. Јужнословенски филолог, 1966-1967, 27, 1-2, s. 207. 


\begin{tabular}{ll} 
vymudrovat, vymyslit & измислити, смислити \\
\hline nazpívat & исиевати (много песама) \\
zpíváním vytvořit, ve větším množství & гласом (по одређеним музичким \\
zazpívat & нормама) извести, отпевати \\
\hline
\end{tabular}

У осталим примерима присутни су и други префикси, као и сам префикс нау различитим значењима, али не у значењу велике мере, одн. кумулативности. Како би се значење прецизирало, префиксални глаголи могу бити допуњени описном дефиницијом, контекстном карактеристиком и глаголском рекцијом у загради.

nabásnit

1. básnicky vytvořit, složit mnoho básní

2. expr. vymyslit si, napovídat něco vymyšleného; nabájit, nalhat

\begin{tabular}{|c|c|}
\hline nadělat & $\begin{array}{l}\text { найравити, начинити (што, много } \\
\text { чега) }\end{array}$ \\
\hline nahledat & 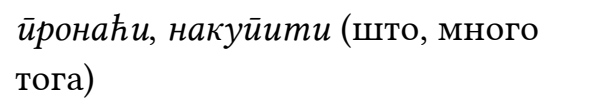 \\
\hline
\end{tabular}

najet

5. hovor. (co) najezdit

иррећи аутом (километре)

najezdit

(co) ježděním vykonat; ujet

ūpeћu, йревалити километре

(колима)

\begin{tabular}{|c|c|}
\hline napáchat & 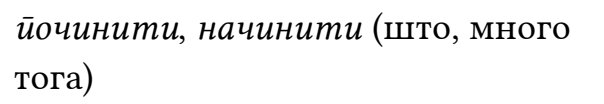 \\
\hline napěstovat & ogīajuти (што, много тога) \\
\hline nasát & усисати, увући, уйити (што) \\
\hline nastlat & $\begin{array}{l}\text { uрострети, разастрети (што, доста } \\
\text { тога) }\end{array}$ \\
\hline našpinit & $\begin{array}{l}\text { зайрльати (што, већу количину } \\
\text { чега) }\end{array}$ \\
\hline navolat & йозвати (кога, више њих) \\
\hline
\end{tabular}


У функцији семантичког еквивалента налазимо и беспрефиксални глагол који је најчешће допуњен описом значења или глаголском рекцијом уз квантитативне елементе.

\begin{tabular}{ll}
\hline nalichvařit & $\begin{array}{l}\text { стећи лихварењем, зеленашењем } \\
(ш т о))^{25}\end{array}$ \\
\hline namozolit & с муком стећи, зарадити (што) ${ }^{26}$ \\
\hline naporoučet & наредити, заповедити (коме што $)^{27}$ \\
\hline našmelinařit, našmelit ob. expr. & $\begin{array}{l}\text { зарадити, стећи шпекулишући, } \\
\text { шпекулацијама, на шпекулацији } \\
\end{array}$ \\
& (што, много тога) \\
\hline
\end{tabular}

Ради поређења, анализирали смо преводну еквиваленцију и у Срйскохрватско-чешком речнику. ${ }^{28}$ Што се тиче обраде кумулативних глагола, у највећем броју ради се о формалној еквиваленцији, као нпр. nabrati - natrhat, načesat, nasbírat; nabrbljati - napovídat, nabreptat, nakecat; nakrasti - nakrást; naloviti nalovit; namesiti - napéci velké množství cukroví; napeći - napéci; naštedeti - našetřit и др.

Ретко су присутни еквиваленти са неким другим префиксом, као и опис значења који такође спада у тип семантичке еквиваленције. Семантичким еквивалентима се дакако прибегава у случајевима када нема формалних еквивалената, или када су они, по мишљењу аутора, неодговарајући. Води се рачуна да префиксални глагол садржи сему квантитета, нпр. ексцесивно значење (přeplácat) или дистрибутивно значење (pozabijet, poštípat), или да опис обухвата квантитативне елементе (mnohé/mnoho, hodně, velké množství).

\begin{tabular}{ll}
\hline načičkati & ověsit ozdobami, preplácat \\
\hline nadeliti & obdarovat mnohé $^{29}$ \\
\hline
\end{tabular}

25 Сматрамо да би глаголска рекција могла бити допуњена и елементом „доста тога“.

26 По нашем мишљењу одговарао би и опис „стећи диринчењем (шта, доста тога)“.

27 Видети нап. 25.

28 JENÍKOVÁ, A. - LEMARIE, K. - SEDLÁČEK, J. - SÝKOROVÁ, S.: Srbocharvátsko český slovník. Praha: Academia, 1982 (даље $S C H C \check{S}$ ).

29 Аутори су одабрали опис значења, мада се нама чини да би могао бити употребљен дериват nadělit чије значење, онако како је дефинисано у SSFС̆, сасвим одговара српском пандану (komu co, při důrazu na množství čeho) darovat, dát, uštědrìt. 
naklati

\begin{tabular}{|c|c|}
\hline naklati & $\begin{array}{l}\text { odporážet hodně dobytka; pozabíjet, } \\
\text { odpravit hodně lidí podřezáním }{ }^{30}\end{array}$ \\
\hline nakotiti & vrhnout mnoho mlád’at \\
\hline narađati & porodit mnoho dětí \\
\hline naštipati & poštípat \\
\hline natrebiti & přebrat velké množství hrachu apod. \\
\hline
\end{tabular}

На основу анализираног можемо закључити да су глаголски деривати са значењем кумулативности присутни у оба језика, а сам префикс па-/на- веома је продуктиван у том значењу. Што се тиче њихове обраде у једнојезичним

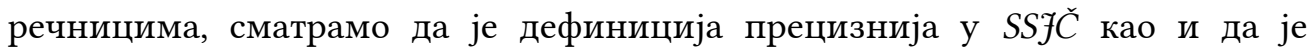
уједначена, док би по нашем мишљењу у РМС дефиниција могла бити ближе одређена према семи кумулативности и да би требало да буде усклађена. То потврђује и $P C J$ у ком су кумулативни глаголи јасно дефинисани, а неуједначеност исправљена. Сматрамо такође да је у ЧСР презентацији и обради кумулативних глагола приступљено детаљно, да је преводна семантизација углавном прецизна и добро промишљена, дакако по питању формалног подударања, а нарочито када се ради о дериватима који представљају семантичке еквиваленте. Наше напомене и понућена прецизирања свакако потврђују неопходност укључивања достигнућа конфронтативних језичких истраживања чешког и српског језика у двојезичну лексикографију, а са друге стране и присутност једнојезичних и двојезичних лексикографских извора у конфронтативно конципираним проучавањима језика уопште.

\section{Литература:}

BELIĆ, A.: Savremeni srpskohrvatski književni jezik II: Nauka o građenju reči. Beograd: Naučna knjiga, 1949.

ČECHOVÁ, M. et al.: Čeština - řeč a jazyk. Praha: ISV nakladatelství, 2000.

DOKULIL, M. - HORÁLEK, K. - HŮRKOVÁ, J. (eds.): Mluvnice češtiny I: Fonetika, Fonologie, Morfonologie a morfemika, Tvoření slov. Praha: Academia, 1986.

GRICKAT, I.: Prefiksacija kao sredstvo gramatičke (čiste) perfektizacije. Južnoslovenski filolog, 1966-1967, 27, 1-2, str. 185-223.

30 Глагол odporážet, присутан у опису значења, у SSFČ је дефинисан као дистрибутивни глагол - postupně odporazit. Вреди поменути да је у PCJ глагол наклати дефинисан и путем дистрибутивног глагола - кољући усмртити већи број (обично животиюа), поклати, те је у питању дериват са истим творбеним средством и акционалним значењем као његов чешки пандан pozabijet који стоји у SCHČS. 
HAVRÁNEK, B. - BĚLIČ, J. - HELCL, M. - JEDLIČKA, A. (eds.): Slovník spisovného jazyka českého I-IV. Praha: Československá akademie věd, 1960-1971.

IVANOVIĆ, M.: Izražavanje akcionalnosti u ukrajinskom i srpskom jeziku. Doktorska disertacija. Beograd: Filološki fakultet, 2013.

JENÍKOVÁ, A. - LEMARIE, K. - SEDLÁČEK, J. - SÝKOROVÁ, S.: Srbocharvátsko český slovník. Praha: Academia, 1982.

KAČANIK, E. et al.: Češko-srpski rečnik I, II. Beograd: SANU, 2001.

KARLÍK, P. - NEKULA, M. - PLESKALOVÁ, J. (eds.): Nový encyklopedický slovník češtiny. Praha: NLN, 2016.

KARLÍK, P. - NEKULA, M. - RUSÍNOVÁ, Z. (eds.): Př́ruční mluvnice češtiny. Praha: NLN, 1996.

KLAJN, I.: Tvorba reči u savremenom srpskom jeziku I: Slaganje i prefiksacija. Beograd: Zavod za udžbenike i nastavna sredstva: Institut za srpski jezik SANU; Novi Sad: Matica srpska, 2002.

KOPRIVICA, V.: Češko-srpski i srpsko-češki rečnik. Beograd: Agencija Matić, 2008.

MITRIĆEVIĆ-ŠTEPANEK, K.: Glagolski prefiksi u funkciji izražavanja količine radnje $u$ češkom i srpskom jeziku. Doktorska disertacija. Beograd: Filološki fakultet, 2015.

STEVANOVIĆ, M.: Savremeni srpskohrvatski jezik I: Gramatički sistemi i književnojezička norma. Beograd: Naučno delo, 1964.

STEVANOVIĆ, M.: Savremeni srpskohrvatski jezik II: Sintaksa. Beograd: Naučna knjiga, 1974.

STEVANOVIĆ, M. et al. (eds.): Rečnik srpskohrvatskoga književnog jezika I-VI. Novi Sad: Matica srpska, 1967-1976.

SVOZILOVÁ, N. - PROUZOVÁ, H. - JIRSOVÁ, A.: Slovník slovesných, substantivních a adjektivních vazeb a spojení. Praha: Academia, 2005.

ŠMILAUER, V.: Novočeské tvoření slov. Praha: SPN, 1971.

ŠTÍCHA, F. a kol.: Velká akademická gramatika spisovné češtiny I. Morfologie: Druhy slov, Tvoření slov. Ćást 2. Praha: Academia, 2018.

TOŠOVIČ, B.: Sposoby glagol'nogo dejstvija v serbskom, chorvatskom i bošnjackom jazykach. Katowice: Wydawnictvo Uniwersytetu Şląskiego, 2009.

UHER, F.: Slovesné predpony. Brno: Univerzita J. E. Purkyně, 1987.

VUJANIĆ, M. et al. Rečnik srpskoga jezika. Novi Sad: Matica srpska 2011.

\section{About the author}

\section{Katarina Mitrićević-Štepanek}

University of Belgrade, Faculty of Philology, Department of Slavonic Studies, Belgrade, Serbia

k.mitricevic@fil.bg.ac.rs 